\title{
A SU PROPIO RITMO \\ At the Rhythm of Cuba's Noticiero ICAIC Latinoamericano
}

\author{
by \\ Jorge Ayala
}

\begin{abstract}
A supporting paper in partial fulfillment of the Masters of Fine Arts degree in Documentary Media
\end{abstract}

Yeates School of Graduate Studies

Ryerson University

Toronto, Canada

(c) Jorge Ayala

2017 


\section{AUTHOR'S DECLARATION}

I hereby declare that I am the sole author of this MRP. This is the true copy of the MRP, including any required final revisions.

I authorize Ryerson University to lend this MRP to other institutions or individuals for the purpose of scholarly research.

I further authorize Ryerson University to reproduce this MRP by photocopying or by other means, in total or in part, as the request of other institutions for the purpose of scholarly research.

I understand that my MRP may be electronically available to the public. 


\begin{abstract}
A su propio ritmo (At lts Own Rhythm) is a short documentary film that reinterprets the audiovisual legacy of the Cuban Revolution, as seen through the lens of the Noticiero ICAIC Latinoamericano (ICAIC Latin American Newsreel). In this paper, I examine the socio-historical context of the Noticiero, present my methodological motivations, the theories that have illuminated my artistic process in the construction of the film, and situate it within documentary film practice at large.
\end{abstract}

KEYWORDS

Santiago Álvarez, Cuba, Cuban Revolution, documentary, ICAIC, montage, newsreels, Noticiero ICAIC Latinoamericano. 


\section{ACKNOWLEDGEMENT}

I would first like to thank my thesis supervisor, Alexandra Anderson. Her experience working in Cuba, and knowledge about the Noticiero ICAIC Latinoamericano were a great source of reassurance while working on this project. I would also like to thank Pierre Tremblay, my second supervisor, for encouraging me to let my imagination fly. Their advice and guidance allowed for my creativity and inner voice to be free. Likewise, to Katy McCormick, Alison Macleod, and all professors and staff at the Documentary Media program at Ryerson University.

I would also like to thank Martha Araujo at ICAIC: her enthusiasm, charisma and guidance opened all doors for me; Dolores Calviño and Luciano Castillo at the Cinématheque of Cuba, and Joel del Río and Fernando Pérez at ICAIC for sharing their experiences and immense wealth of wisdom; Cecilia María Alpízar Hernández at the ICAIC Labs for her patience and collaboration, and the staff at the Fresa y Chocolate Cultural Centre, Cine Charles Chaplin, and ICAIC at large. Especial thanks to Dany Celeiro at EICTV for his endless tenacity and resourcefulness, and my tech crew in Havana for their hard work and creative input.

Finally, I must express love and gratitude to my family for their infinite love and patience, and to William Ross for his unconditional support, and for always believing in me. My goals would have been never achieved without them.

Jorge Ayala 


\section{TABLE OF CONTENTS}

Introduction 1

Socio-Historical Context 3

Methodology 14

Documentary Relevance 31

Conclusion 36

$\begin{array}{ll}\text { Bibliography } & 38\end{array}$ 


\section{INTRODUCTION}

"Art is not a mirror which reflects the historical struggle, but a weapon of that struggle" (Dziga Vertov)

On December 17, 2014, then president of the United States, Barack Obama announced in a press conference that "the United States of America is changing its relationship with the people of Cuba." Simultaneously, in a televised speech from Havana, Cuban president Raul Castro announced "we have embarked on the task of updating our economic model in order to build a prosperous and sustainable Socialism". This surprising event marked a moment in Cuban history that seemed as radical as the events of the Cuban Revolution itself. Interest in the small Caribbean island not seen since the fall of the Soviet Union, spiked all over the media, and every diplomatic move by either side was heavily scrutinized. In the post-revolution years, Cuba had gradually restricted access to foreign press, filmmakers and tourists. Images of life on the island were mostly obtained from locally produced films which, due to the US embargo, had very limited distribution.

Slowly reopening to tourism in the early 1990 s as the heavily Soviet-subsidized economy collapsed, Cuba retained a slight veil of mystery around itself. Snapshots of beautiful but crumbling Havana buildings, colourful 1950s American cars, and the Buena Vista Social Club became the cliché imagery of an island exoticized by tourists, visitors and foreign media alike. In 2017, a hashtag search about Cuba on Instagram, reveals a similar pattern of clichés about the Cuban image. But in the post-revolutionary 
years, the immense majority of images coming from Cuba, were those of their films. Carrying heavily political, agit-prop content, Cuban films revealed the aspirations of a nation that was bent on reorganizing itself into a socialist society. Launched in 1960, the Noticiero ICAIC Latinoamericano (ICAIC Latin American Newsreel), a weekly newsreel produced uninterruptedly for 30 years, presented to Cuban filmgoers a panorama of the profound transformations the country was experiencing. Through its history, the newsreel's content would be a reflection of the cultural policies of the government, and would also document other revolutionary struggles in Latin America and the rest of the 'Third World'.

A su propio ritmo (At Its Own Rhythm) is a short documentary film that reinterprets the audiovisual legacy of the Cuban Revolution, as seen through the lens of the Noticiero ICAIC, by using montage techniques that echo the aesthetics and ideas about the role of documentary filmmaking championed by its director, Santiago Álvarez. In this paper, I will present the historical context of the Noticiero, and its role as a creative workshop and school for filmmakers in Cuba. I will also offer a contextual and critical assessment of my project. 


\section{SOCIO-HISTORICAL CONTEXT}

Shortly after midnight on January 1, 1959, as New Year's celebrations sizzled around Cuba, Fulgencio Batista, ruler of the nation since seizing power in a military coup on March 10,1952, fled to the Dominican Republic. As news spread through the Island, a new chapter in the revolutionary process spearheaded by the 26th of July Movement was set off. Named after the date of the failed attack on the Moncada Barracks in 1953, the revolutionary organization was part of a larger guerrilla movement that carried operation on urban and rural fronts. Fidel Castro, who led the rural arm of the resistance based in the Sierra Maestra mountain range, would eventually consolidate power and lead the transformation of the island into a socialist society.

A charismatic leader, Castro had astutely used Cuba's radio and television stations to galvanize public opinion and win support for the revolutionary movement. Once in power, the young revolutionary government, sharply aware of the power of the media to transform society, created the Cuban Institute of Cinematographic Arts and Industries (ICAIC) on March 24, 1959. The first cultural institution created by the young revolutionary government, ICAIC would be in charge of film production and distribution. Cinema would become the main medium of the Revolution, as stated by the Law 169 of 1959 that created the Insittute: “...cinema constitutes, due to its characteristics, an instrument of opinions that forms individual and collective consciousness and can contribute to deepen and purify the revolutionary spirit and sustain its creative impulse"1.

${ }_{1}$ Amaya, Héctor. Screening Cuba: Film Criticism and Political Performance during the Cold War (Chicago: The University of Illinois Press, 2010), 15. 
Michael Myerson gives an account of the Cuban film industry before the Revolution as "a source of cheap tropical locations for Hollywood studios; there was a poorly equipped dubbing studio to help Cubans enjoy North American film fare; the Batista dictatorship allowed some amateurish self-serving newsreels to proclaim its good deeds, which turned out to be as stirring as the history of Greenland."2 Assigned with the task to properly develop their film industry, and faced with the urgency to document the rapid changes that the nation was experiencing, ICAIC reorganized the existing commercial newsreel enterprise, and on June 6, 1960, the Noticiero ICAIC Latinoamericano (ICAIC Latin American Newsreel) was launched.

News films first appeared in Cuba in 1920 with Suprem Film by Juan Valdés González, which combined news, high society notes and commercial ads. In 1924, Actualidades Cubanas (Cuban Actualities) became the first regular newsreel organized in Cuba. In 1928, the Cuban government, through the Department of Public Works created a film department. Its mandate was to produce the Noticiario de la Secretaría de Obras Públicas (Public Works Department Newsreel), to document events of national importance. The material created by this newsreel became part of the first audiovisual archive of Cuba. Manolo Alonso, one of the most important filmmakers in pre-revolutionary Cuba, started the Noticiario Nacional in 1942, and eventually became the leading newsreel producer in Cuba. He had a keen interest in acquiring film archives

2 Myerson, Michael, ed. Memories of Underdevelopment: The Revolutionary Films of Cuba. (New York: Grossman, 1973), 18. 
from other companies and amassed a considerable collection that would later become part of the archive of the Cinematheque of Cuba in $1959^{3}$.

Eduardo Hernández, a cameraman with a long and celebrated career in newsreels, abandoned Cineperiódico in 1954, and started its own newsreel, Noticuba. Hernández became Cuba's first cinematographic reporter to ascend to the rebel camps at the Sierra Maestra mountain range. His privileged, albeit risky access to the frontline allowed him to capture images with a rich documentary value. The project, aptly titled Sierra Maestra, would see its post-production process taking place in secrecy, in order to avoid retaliation from the Batista regime. It was publicly exhibited after the revolutionaries took power under the title De la tiranía a la libertad (From Tiranny to Freedom). Similarly, Cineperiódico presented El gran recuento (The Big Retelling) (1959), a 90 minute documentary shot in April, 1958, which reconstructed, alongside additional archival material, the most relevant events of the Batista dictatorship ${ }^{4}$.

Newsreels in Cuba amounted to a business of considerable size. Their model was similar to private newsreel enterprises anywhere else, with heavy reliance on commercial sponsorship from corporations, mid-size business, as well as from individuals and private clubs from the upper classes. ${ }^{5}$ All media channels in the island

3 Garcia, Alicia, and Sara Vega. "El Periodismo Cinematográfico: Aventuras, Peripecias y Trascendencia". In Coordenadas del Cine Cubano 2, ed. Mario Naito López, trans. Jorge Ayala (Santiago de Cuba: Editorial Oriente, 2013), 96.

${ }_{4}$ Arturo Agramonte and Luciano Castillo. Cronología del Cine Cubano Vol.III, trans. Jorge Ayala (La Habana: Ediciones ICAIC, 2016), 473.

97.

5 Chanan, Michael. Cuban Cinema (Minneapolis: University of Minnesota Press, 2004), 
were eventually nationalized, and the transition period from the commercial approach of media production and broadcasting to a government-controlled system took a few months. All the newsreels that were operational in early 1959 continued operating and became instrumental in the documentation of the first months of the Revolution. Eventually they became part of ICAIC, as well as all other commercial production companies, distributors and movie theatres ${ }^{6}$.

In the 1940 s and early 1950 s, Cuba had emerged as a tropical playground for Americans, a city filled with casinos, nightclubs, brothels, heavy drinking and drugs, only 90 miles away from Miami. The visual imaginary about the island as seen in advertising, as well as Hollywood and Mexican films, was a reflection of that reality. Films locally produced between 1930 and 1958 were also a reflection of the those models, with heavy emphasis on melodramas with a music and dance, sunny backdrop. The Cuban reality was not reflected on the screen. Instead, audiences were presented with "a false Cuban reality plagued by maracas, rumba dancers and by completely unconcerned people, always happy or conversely, involved in futile dramas."7

A film school was not established in Cuba at the time, and very few individuals had training in filmmaking. Tomás Gutiérrez Alea and Julio García Espinosa, who were part of the initial team joining ICAIC, did advance film studies at the Centro Esperimentale di Cinematografia in Rome, where they were exposed to the theoretical

${ }^{6}$ Andres R. Hernandez, "Filmmaking and Politics: The Cuban Experience". The American Behavioral Scientist (pre-1986), no. 17 (1974): 379.

7 lbid., 363. 
and aesthetic propositions of Italian neorealism. With its limited equipment approach, use of non-professional actors, as well as humanist affinity for the poor and working class, the neorealist style seemed to match the material realities and needs of the ICAIC at the time of its creation. Santiago Álvarez, the director of the Noticiero for the 30 years of its existence, had studied literature and philosophy and possessed no experience in filmmaking. He started developing his craft under the umbrella of documentarians such as Joris Ivens, Theodor Christensen and Chris Marker, who visited Cuba during the initial months of the Revolution, and helped organize ICAIC and train its staff. ${ }^{8}$ During his visits, Ivens made two films: Carnet de via (Travel notebook) and Cuba pueblo armado (Cuba, a people armed) with untrained Cuban crews, who learned how to make films on the go. This approach would be one of the motivating ideas for establishing an apprenticeship system requiring directors to do work in documentary or newsreel before moving onto fiction. ${ }^{9}$ This system was the standard until the foundation in 1986 of the International School of Film and Television (EICTV) in San Antonio de los Baños, a small town 20 km outside Havana.

\section{On September 2, 1960, Fidel Castro announced in the First Declaration of} Havana the socialist character of the Revolution, making official the intentions of the new government to transforming individual identities of the public into a collective force, and reconfiguring the role of the individual into a newly-defined collective. ICAIC and Cuban cinema would become key instruments that would help reflect the dramatic

8 Malitsky, Joshua. Post-Revolution Non-Fiction Film: Building The Soviet and Cuban Nations (Bloomington: Indiana University Press, 2013), 7.

9 Chanan, Cuban Cinema, 198. 
changes faced by their new reality, and reconfiguring a national identity that would move Cuba from an urban, colonial and decadent entity dominated economically and culturally by the United States, into a unified national collective that would bring to the forefront the neglected needs of the rural, and would be committed to the national liberation. ${ }^{10}$

Julianne Burton argues that Latin American documentary filmmakers would become "self-appointed ethnographers in search of the 'true face' of their people, of the custodians of national culture, of the true exemplars of national identity", ${ }^{11}$ and references Argentinian filmmaker Fernando Birri, who affirms that the function of the social documentary in Latin America would be to rectify the "false image (of the people) presented by traditional cinema" 12 . One of the strategies of the Noticiero was to articulate a new relationship between the urban and rural citizens. Images of rebel army peasants marching through Havana, ${ }^{13}$ or the building of new homes in the countryside ${ }^{14}$ would highlight this new balance. But the efforts to transform the concept of citizenship in Cuba would reach its height with the National Literacy Campaign of 1961, a massive education effort that mobilized 100,000 mostly urban student volunteers (Brigadistas) who were sent into every village in the island, bringing the literacy rate from $76 \%$ to $96 \%$

10 Malitsky, Post-Revolution Non-Fiction Film, 15.

11 Burton, Julianne. "Democratizing Documentary: Modes of Address in the New Latin American Cinema, 1958-1972". In: The Social Documentary in Latin America. (Pittsburgh, University of Pittsburgh Press, 2009), 77.

12 lbid.

13 Noticiero ICAIC Latinoamericano. Episode 7. July 18, 1960. Digital file.

14 Noticiero ICAIC Latinoamericano. Episode 41. March 13, 1961. Digital file. 
in a 15 month period. ${ }^{15}$ The Noticiero constantly informed on the advances of the campaign (episodes $22,31,39,45,50,54,63,75,76,77,82$ ), and some of these images were later used in Historia de una batalla (Story of a battle) ${ }^{16}$, a 1961 documentary by Manuel Octavio Gómez celebrating the campaign. The Noticiero reflects the revolutionary "willingness to rediscover and reinvent the country"17 and the efforts of the new government's cultural policies to "bring to the light an identity that was there, although completely submerged", ${ }^{18}$ bringing to the forefront the rural and Afrocuban elements of the national culture that had been traditionally considered primitive and lowbrow.

While the revolutionary government focused on eradicating illiteracy from Cuba through the Brigadistas, ICAIC launched its own media literacy campaign. Using Marxist models of media analysis, the Noticiero made evident its analytical approach to news in order to mark itself as something more than just a form of entertainment, introducing audiences to the mechanisms used by media Ito shape subjectivities, or by breaking down the stereotypical depiction of blacks in Hollywood films. ${ }^{19}$ The 'decolonization' of the Cuban film industry and intervention of all US-owned film distribution companies is

\footnotetext{
15 McDonald, Theodor. Making A New People: Education in Revolutionary Cuba (Vancouver: New Start Book, 1985), 55.

16 Historia de una batalla, directed by Manuel O. Gómez (1961; Havana, ICAIC), Digital file.

17 Joel del Rio (Cuban film scholar) in discussion with the author in Havana, October, 2016.
}

18 Dolores Calviño (Vice-Director of the Cuban Cinematheque) in discussion with the author in Havana, October, 2016.

19 Malistky, Post-Revolution Nonfiction Film, 86. 
also commented upon. Images of workers using sledgehammers to knock down the marquees on top of the former headquarter buildings of foreign film companies in Havana are shown at the end of episode 49.20 In order to bring its own audiovisual literacy campaign all over the country, ICAIC launched a Mobile Cinema Unit in 1961. In 1959, 595 cinemas existed in the country, 149 of them in Havana, and the rest located mostly in provincial capitals or mid-size towns, leaving the countryside vastly underserved 21 . In order to bridge the gap, mobile projection units were sent to every corner of the island, and by 1970 there were 102 units deployed. Trucks, and later on, mule and boat units, carrying a projector, screen, and generator, showed an episode of the Noticiero, one or more short documentaries, and a feature film. The success was tremendous and by 1962 a total of 4,603 projections were organized for a total of $1,239,528$ viewers. By 1970 , the mobile units had reached over 12 million viewings. ${ }^{22}$ Joel del Rio considers the mobile cinema units as "one of the most extraordinary experiments ever undertaken in Cuba." ${ }^{23}$ At an international level, the newsreel division of ICAIC collaborated in the training of technicians, and creation of other national newsreels such as the INCINE Newsree/ in Nicaragua (its $35-\mathrm{mm}$ black \& white film

20 Noticiero ICAIC Latinoamericano. Episode 49. May 29, 1961. Digital file.

21 Hernández, Filmmaking and the Cuban Experience, 370.

22 Pardo, José Manuel. El cine-móvil [sic] ICAIC, trans. Jorge Ayala. Cine Cubano, no. 12, (1972): 96.

23 Joel del Río, in discussion with the author in Havana, October, 2016. 
reels were developed, edited and printed in Cuba) ${ }^{24}$, Grupo Experimental de Cine Universitario (GECU) in Panama, and Kuxa Kanema (Mozambique). ${ }^{25}$

During the 1960s, dealing with the present was the main thematic preoccupation of ICAIC, and the Noticiero focused on exploring and analyzing the ever changing conditions of the still young revolution. Themes such as agrarian reform (episodes 24, $50,104,425$ ), industrialization (episodes $3,22,24,28,29,33,52,68,110,119,133$, 142, 267), housing (episodes 26, 41, 79, 167, 241, 308, 346, 368, 417), and other topics of immediate relevance were constantly showcased, informing the population about the changes brought up by newly established government programs, as well as showcasing their achievements. The growing commercial relationship with the Soviet Union was also heavily promoted, and reports about the everyday life and achievements of socialist block countries were also a common feature in the newsreels (episodes 29, 35, $53,54,56,62,70,81,84$, etc.).

In the 1970s, both ICAIC and the Noticiero would turn into the past as the departure point to explore Cuba's complex reality. The First National Congress on Eduction and Culture (1971) was organized by the government with the goal to delineate clearly the role of educators, artists and intellectuals in helping increase the revolutionary awareness by the masses. Up until then, cultural affairs were dictated by

\footnotetext{
24 Buchsbaum, Jonathan. Cinema and the Sandinistas: Filmmaking in Revolutionary Nicaragua (Austin: University of Texas Press, 2003), 45.

25 Schefer, Raquel. "The Return of The Newsreel (2011 - 2016) in Contemporary Cinematic Representations of the Political Event." Cinema Comparat/ive Cinema. Vol IV. No.9, 2016. p.65.
} 
the National Council for Culture (CNC), which became the Ministry of Culture in 1976. One of the demands directed at ICAIC was to dedicate its efforts to focus on historical topics such as the birth of the Nation and its battles for independence. ${ }^{26}$ The result was an increase in newsreels, documentaries, and films "with a historical character as means to link the present with the past"27. The Congress also declared the need to "contain any form of deviance among the youth", 28 and a wave of austerity and moralization would guide all cultural affairs for the next few years (a period euphemistically known as "the grey years"). Once infamous Havana nightlife was shut down, rock music was banned and gestures such as wearing long hair, listening to foreign music, or displaying 'deviant' sexual lifestyles were condemned and repressed.29

The relative political independence of ICAIC as a cultural institution allowed it to challenge the new cultural guidelines set by the Congress. For instance, Santiago Álvarez was the first film director at ICAIC to champion the musical output of the Sonic Experimentation Group (Grupo de Experimentación Sonora or GES) by incorporating it into the soundtracks of both the Noticiero and his own documentaries. ${ }^{30}$ Created as an ICAIC branch in 1969 by Alfredo Guevara, founding director of ICAIC and personal

26 Joel del Río, October 2016.

${ }_{27}$ Rodríguez, Paul A. Schroeder. "The Heresy of Cuban Cinema." Chasqui 37, no.2 (2008): 127.

28 Perna, Vincenzo. Timba: The Sound of the Cuban Crisis (Burlington, Ashgate Publishing Limited, 2005), 31.

29 Ibid.

30 Sarusky, Jaime. Una Leyenda de la Música Cubana: Grupo de Experimentación Sonora del ICAIC, trans. Jorge Ayala (La Habana: Editorial Letras Cubanas, 2006), 38. 
friend of Fidel Castro since their student times at University of Havana, GES functioned as a musical workshop that allowed young musicians to experiment with sound in a different direction from the folkloric traditions of Cuban music. Inspired by a trip to Brazil, and impressed by the music of Chico Buarque, Caetano Veloso, Gilberto Gil, and other musicians from the Tropicália movement, Guevara approached Leo Brouwer, a Julliardtrained young musician, to help him set up an experimental workshop to advance the Cuban popular music repertoire ${ }^{31}$. Some the members of the GES were seen with suspicion by the authorities, and Pablo Milanés, who later became one of Cuba's most important musicians, had been himself interned a few years before at the UMAP (Military Units to Aid Production), Stalinist-type camps where disenfranchised youth were sent for 'rehabilitation'32. Music by GES was rarely played on the radio and their live shows had no official media support, but the Noticiero featured some of the GES musicians in musical numbers (episodes $411,428,532$ ). Álvarez included rock music in the Noticiero soundtracks (episodes $247,459,472,511,1102$ ) and some of his own documentaries, most notably 79 Springs. ${ }^{33}$

In the late 1970 s and early 1980s, the Noticiero started taking a critical stance against the socio-economical conditions of the Revolution, taking the crews to the streets and presenting analytical critiques of still unsolved problems such as scarcity, bureaucracy, and urban and architectural decay (episodes 821, 827, 829, 902, 957,

31 lbid., 28.

32 Chanan, Cuban Cinema, 7.

3379 Springs, directed by Santiago Álvarez (1968; Havana, ICAIC), Digital file. 
1021, 1034, etc.). Fernando Pérez, arguably Cuba's most celebrated film director alive, and who started his directorial career in the Noticiero, comments that this approach attracted the attention of bureaucrats who attempted to stop the release of some of the episodes, but Álvarez defended the team before the authorities and was able to overcome the censors ${ }^{34}$. Other accounts by José Padrón, a documentary filmmaker who was also part of the Noticiero team, mentions that although all episodes were indeed released, some of them would be taken out of circulation before finishing their cycle around the country, and even a mere few days after their initial release ${ }^{35}$.

Since the 1985 speech by Soviet premier Mikhail Gorbachev in Leningrad where he admitted the economical woes faced by the Union, a relentless process of restructuring (Perestroika, in Russian) took place in the Communist commonwealth. One of the consequences of Perestroika was the gradual reduction of the generous commercial subsidies to Cuba until their complete disappearance with the dissolution of the USSR. The dramatic economic upheaval caused by the loss of Soviet support generated the biggest crisis faced by Cuba, and the country entered into what would would be euphemistically known as a "Special Period in Times of Peace". Budgetary cuts made its way through all levels of government, and it is in this context that the Noticiero faced its slow death. On another front, a reunified, capitalist Germany absorbed ORWO, an East German film company that supplied the raw black and white film used for the production and distribution of the Noticiero. Unable to pay with foreign

34 Fernando Pérez (film director) in discussion with the author in Havana, October, 2016.

35 Alexandra Anderson, "Reflecting on Reality: The Place of Truth in Cuban and Canadian Documentary” (master's thesis, York University, 2003), 79. 
currency for raw stock and chemicals for film development, and facing major restructuring of ICAIC, the last episode of the Noticiero was released on July 6, 1990.

One of effects of the Cuban economic crisis in the 1990s was constant electricity blackouts, which exposed their film archives to less than desirable conditions in the tropical climate of the Caribbean island. These extreme conditions brought the reels into a state of serious damage risk. Stored in less than optimal conditions for years, the Noticiero's original $35 \mathrm{~mm}$ film material faced the threat of permanent loss. The Cinematheque of Cuba, under Dolores Calviño, launched a staunch campaign to save the archives from permanent loss. Intense lobbying allowed them to successfully have the Noticiero included in UNESCO's Memory of The World Register in 2009. While this status didn't guarantee any economical benefits, it was a precedent that allowed them to secure interest from international media consortiums. ${ }^{36}$ In 2012, the Cinematheque of Cuba secured a restoration and digitization agreement between the French Institut National de l'Audiovisuel (INA) and ICAIC. Details of this agreement are still unknown to me, but in general terms, it allows INA to use and commercialization of the restored material. Up to November, 2016, a total of 500 newsreels had been restored and digitized, and its original reels returned to Cuba, along with its corresponding copies in HD and SD formats. As of August 1, 2017, INA has made available online on their website selections of the Noticiero up to episode 1029 (first released July 11, 1981). All the restored clips available on the INA online platform (http://www.ina.fr) have the INA logo watermarked on them.

36 Dolores Calviño in discussion with the author in Havana, October, 2016. 


\section{METHODOLOGY}

My interest in the Noticiero started casually. For one of my first year classes with professor Marc Glassman, I prepared a presentation on one of four Latin American Documentary filmmakers: Fernando Solanas, Octavio Getino, Patricio Guzmán, or Santiago Alvarez. At this point in my process, I was focused on working with Cuban content, and I chose Álvarez, and proceeded to research literature and material on him. While there was a fair amount of written material Álvarez, there was not a lot of audiovisual content available. I considered the lack of material understandable given the relative isolation of Cuba in the international sphere. The most popular film by Álvarez was NOW!, 37 a 5 minute montage of stock footage and still photographs offering a compelling vision of the struggle for racial equality at the height of the civil rights movement in the United States. My curiosity was sparked by the slickness of the montage, its lack of synch sound or spoken word, and the effectiveness of its message via a pop song. The remix aesthetics displayed in the film struck a chord with me: my first experiences working with video in the early 2000 s were based on re-appropriated material from digitized old tapes, DVDs or material found on the Internet. These experiments led me to eventually find work as a VJ in clubs and massive dance events. By watching this film, I was confronted with one of the early examples of the technique I had used, albeit in an analogue medium.

Further research led me to find out that NOW! was originally shown on August 23, 1965 in Cuba as the closing section of the episode 272 of the Noticiero ICAIC

${ }_{37}$ Now!, directed by Santiago Álvarez (1965; Havana, ICAIC), Digital file. 
Latinoamericano. This was the first time I learned about the Noticiero and Cuban documentary newsreels, and frustrated by my inability to find any copies online, I set on a trip to Havana in December, 2015, intent in obtaining copies of the newsreel.

Through personal connections I was referred to Martha Araujo, a Cuban TV personality and Communications Coordinator at the Documentation Centre of the ICAIC. She showed interest in my project idea, and was instrumental in helping me navigate the bureaucracy at ICAIC. At this point, I encountered what would be a constant obstacle during my research: the Cuban tech gap. Araujo had made arrangements for me to visit the Videotheque of the EICTV, where I obtained several episodes on DVD which were made available to me. She also introduced me to Cuban filmmakers, some of which had worked in various capacities at the Noticiero. One of them in particular, Jorge Luis Sánchez, mentioned his 2010 book, Romper la tensión del arco, the only book published in the island dedicated exclusively to Cuban documentary cinema. In total, I was able to obtain copies of 84 episodes, most of which were produced in the 1980s. A few of them were from the 1960s, and only a couple of them from the 1970s. During production time, I was able to obtain restored, lo-resolution digital copies of the first 30 newsreels, for a total of 114 episodes.

\section{PRODUCTION}

Production duties took place in Havana in October, 2016. I was able to arrange formal interviews with 4 different people: Luciano Castillo: Film scholar, current director 
of Cinematheque of Cuba; Dolores Calviño: Vice Director of Cinematheque of Cuba, former Vice Director of EICTV and key engine behind the restoration initiative of the newsreels; Fernando Pérez, arguably most important Cuban film director today, who started his training in the Noticiero; Joel del Rio, film scholar and critic. All interviews were shot at the Fresa y Chocolate and Charles Chaplin cinemas, both venues neighbouring the ICAIC headquarters, where all the interviewees work. This decision allowed for their easy and fast access to the venue, avoid transportation costs, and simplifying the planning process, as no location permits were needed. I also some informal interviews with Francisco Cordero, Chief of Patrimony at ICAIC; Cecilia Alcócer, Manager of the ICAIC Archives \& Lab where the original reels of the Noticiero are stored. In April 2016, I had the opportunity to meet in London Cuban film scholar Michael Chanan,, author of the book Cuban Cinema, and arguably one of the most influential researchers of Cuban film, who provided valuable insights into the history of the Noticiero.

I conducted scholarly research at ICAIC's Documentation Centre. Housed on the second floor of the ICAIC headquarters, the Centre resembles a typical library dating back to the 1980s. Working at the Centre came with its own set of difficulties: the irregularity of their working hours, lack of databases for searching material as well as photocopy or scanning equipment, or external factors such as power outages. But in typical Cuban fashion, there is always a workaround for each challenge. I found a book that served as a substitute of electronic databases, Indice de la revista Cine Cubano (1960-2010). The book organizes by topic the 178 issues of Cine Cubano, a periodical 
dedicated to film, with emphasis on Cuban and Latin American film in general. I consider this periodical as an invaluable source of information on Cuban cinema, especially from the 1960 - 1990 period. Searching online for Cine Cubano entries only resulted on articles from 1972 on, so finding material for the 12 prior years was crucial. Faced with a lack of scanning equipment, my iPhone became my scanner, allowing to create PDFs from the pictures I took from all the articles I needed to consult.

I also obtained permission to film at ICAIC's Filmic Archive, formerly colour processing labs, located in the Nuevo Vedado neighbourhood of Havana. Film is no longer processed at this location, and the facilities are now used to house under controlled conditions, the original $35 \mathrm{~mm}$ reels of all Cuban films shot in colour, as well as the reels containing the Noticiero. While the storage specs are not ideal, and faced with a lack of resources to meet full optimal storage conditions, the ICAIC made the decision to ensure stable levels of temperature and humidity, thus meeting the minimal requirements that avoid further damage to the film stock and ensure its longevity. I was able to shoot the storage vaults, as well as other work areas, full of equipment now in disuse. I also captured some of the employees at work. Some of their current duties are related to maintaining the film, using moviolas to 'air' the stock, as well as looking for sign of deterioration or damage.

\section{POST-PRODUCTION}

As part of my methodology, I set up a couple of rules that would guide my postproduction process. Rule one: I would not start editing until I hadn't chosen a title for the 
film. Rule two: I would choose the music and build the soundtrack simultaneously with the editing process. These rules meant to emulate the creative process that Santiago Álvarez had followed in his own work. Talking about his creative process in an interview in the Cuban Cinema journal, Álvarez commented on his editing process: "..until the idea of a title for a documentary doesn't occur to me, I can not start editing. I must have a title thought out, taking it as a starting point to structure a documentary." ${ }^{38}$ Regarding the construction of his films' soundtracks, he explained: 'In short, when I edit, I don't do as others who finish editing and then add the music, but I choose the music as I edit." Alvarez claimed that his work as a musical archivist in $\mathrm{CMQ}$, a radio and television network in Havana, gave him the training to develop the musical sensitivity he imbued in his work.

I also decided that the film would not feature the standard talking-head interviews. There were two reasons: first, I wanted to stay away from what is perhaps the biggest convention in documentary films today; second, by making the voices anonymous, I wanted to reflect the socialist idea of the voice of the group taking precedence over the voice of the individual. Once I was ready to start editing, I didn't have a script, or a coherent structure to follow. My first step was to automate the export process of the VOB files containing the episodes, and extracted from the DVDs I had obtained in Cuba. VOB is the container format in DVD-Video media, which are usually stored as MPEG2 files. In order to avoid further degradation of the material, I

38 Castillo, Luciano and Manuel Martínez Hadad. "Una entrevista inédita. Santiago Álvarez: (1919-1998). El documental como una actitud ante la vida". Cine Cubano, no. 145, (1999): 32. 
transcoded the files onto Apple ProRes 422 format using FFmpeg, a free software for conversion of audio and video files. Although Apple ProRes itself is a lossy video compression format (albeit the loss is negligible), it keeps a higher quality than most user codecs, and its data rate is manageable by the computer I used to edit the material. I then imported every digital file I had encoded with FFmpeg into Apple's Final Cut Pro X. I had also considered using Adobe Premiere but after carefully testing both options, the comprehensive database capabilities that Final Cut offered, crucial for the daunting editing process ahead of me, tipped the balance in its favour. To classify the material, I broke up each episode of the Noticiero into shots, and tagged each shot with metadata referring to the images shown. Some examples of the keywords I used were: Fidel Castro, Brazil, books, sugar cane, crowd, airplane, parade,, animation, etc. These keywords would allowed me to reorganize the material according to the subject I would be working at each step of the process.

I didn't want to create a journalistic documentary, but at the same time, it was my desire to make the history clear for the audience. During the interview process (indeed the journalistic aspect of my process) in Havana, I followed a script that approached my questioning about the history of the Noticiero in a rough chronological order, followed by a personal inquiry of their individual (at a personal and a professional level), and collective memories (both as a producer/scholar, and as an audience member). I decided to follow this loose structure, using chronology as the main organizing principle for the film. 
For the film's soundtrack, I initially had the idea to use only music made in Cuba or by Cuban musicians, and made a compilation of Cuban popular music ranging from the mid-1950s up to the mid-1990s. As my editing process advanced, and after repeated playback of each Noticiero episode I had available, I started to become more attuned to the richness and eclectic reach of the music selection in each episode: classical, baroque, jazz, Afro-Cuban rhythms, rock, musique concréte, tropicália, noise, electronic music, as well as folk music from every corner of the world. This realization made me question my initial approach to the music selection, and I started to expand my possibilities by using the soundtrack of the Noticiero itself as inspiration. The music of the Noticiero has not been discussed in depth by scholars, and my own exploration helped me realize that music was an aspect that i wanted to bring forth in my film, and eventually became the driving force on my editing process.

Having chosen the title from a quote from Joel del Rio, who states: "When ICAIC is created, Cuba starts marching at its own rhythm", ${ }^{39}$ I immediately realized that the idea of rhythm, an element of music closely related with time, could help me organize my ideas in a similar fashion to a musical work. I organized the film into sections or "movements" that are distinct in terms of mood and tempo, and identified each section with the major "battles" that the Revolution fought against, as follows:

- Overture (Battle Against Batista)

- First Movement (Battle Against Counterrevolution)

- Second Movement (Battle Against Underdevelopment)

39 Joel del Río in discussion with the author in Havana, October, 2016. 
- Third Movement (Battle Against Imperialism)

- Fourth Movement (Battle Against Dogmatism and Stagnation)

- Epilogue (Battle for Preservation).

Overture and First Movement (Battle Against Counterrevolution)

The film opens with a quote (white text on a black background) by Julio García Espinosa, Cuban filmmaker, scholar, and director of ICAIC between 1980-1990: "A country without images is a country that doesn't exist". This phrase sets the tone for the exploration of the history of the Noticiero. It is followed by a quote extracted from a 1960 speech by John F. Kennedy then a US Senator that describes some of the conditions present at Cuba during the guerrilla struggle of the 26 th of July Movement. 40 It is paralleled by Concierto Para Bongo by Dámaso Pérez Prado, a Cuban composer and multi-instrumentalist, self-proclaimed and popularly known as "The King of Mambo". This piece was recorded in Mexico City (where he lived since 1949) circa 1957, at a time when mambo, cha-cha-cha and other big orchestra sounds were very popular in the international market (mainly Mexico and the United States). They provided the soundtrack at the nightclubs, cabarets, and casinos which made Havana infamous in the late 1950s, at the same time that the guerrilla struggle against the Batista government was in full force.

40 John F. Kennedy. "Remarks of Senator John F. Kennedy at Democratic Dinner, Cincinnati, Ohio, October 6, 1960", John F. Kennedy Presidential Library and Museum, https://www.jfklibrary.org/Research/Research-Aids/JFK-Speeches/CincinnatiOH_19601006-Democratic-Dinner.aspx 
Concierto para bongó is an energetic, percussion-heavy piece that counterpoints the images of the rebels descending from the mountains in their fight against the Batista regime, and their triumphal arrival in Havana in early January 1959. A short rhythmic interlude connects the overture with the First Movement, which resumes with a relentless rhythm as the story jumps to April, 1961, a year after the release of the Noticiero, with images of episode \#47, which chronicles the failed US-backed invasion to Cuba in Playa Girón (Bay of Pigs). This episode would be later re-edited and released as Muerte al Invasor, ${ }^{41}$ a 16-minute documentary co-credited to Tomás Gutiérrez Alea and Santiago Álvarez.

Second Movement (Battle against Underdevelopment)

In this section there is a shift in mood and tempo. We slow down into a more introspective tone as the educational aspect of the Noticiero as de-facto film school and training ground in Cuba is discussed. As counterpoint, the Revolution's own educational and cultural agenda is presented. At this point, we hear Gandinga, Mondongo y Sandunga (1963) by the Quinteto Instrumental de Música Moderna (Modern Music Instrumental Quintet), a seminal Afro-Cuban jazz band founded in 1959 by pianist Frank Emilio. This piece was featured in the documentary Nosotros La Música, ${ }^{42}$ a 1964 documentary by Rogelio París. Accompanying images from the 1961 Cuban Literacy Campaign, the marching rhythms of Himno Alfabetizador de la Brigada Conrado Benítez (1961) by Raúl Ferrer, the campaign's anthem. From the anthem chords we

\footnotetext{
${ }^{41}$ Muerte al Invasor, directed by Santiago Álvarez and Tomás Gutiérrez Alea (1961; Havana, ICAIC), Digital file.

${ }^{42}$ Nosotros La Música, directed by Rogelio París (1964; Havana, ICAIC), Digital file.
} 
fade into white noise, and then we hear the voice of Julio Batista Delgado, first narrator of the Noticiero and an iconic figure in Cuban radio, announcing the feats of Andriyan Nikolaiev, a Russian cosmonaut who piloted the Vostok III spacecraft. Backed by voices in Russian, rumble and white noise, the image of the cosmonaut obliquely references the ever-increasing presence and influence of the Soviet Union in Cuban affairs, which would fluctuate between different levels of intensity for the next 3 decades.

At this point, we reach the height of 1960 s idealism. Lola Calviño offers a personal insight into the goals of ideals of her generation: "Era una juventud que quería revolucionar todo" ("We were a generation that wanted to revolutionize everything"). In an homage to Gutiérrez Alea, I use images from his film Memories of Underdevelopment ${ }^{43}$ that were captured on the streets of Havana in a Free Cinema style using a hidden camera. The tropicália guitars and percussion of Queremos Guerra ("We Want War") interpreted by Brazilian songwriter Gilberto Gil and recorded for the IV Festival of Brazilian Popular Music (1968), features Jorge Ben, its writer, and Caetano Veloso, all key figures of Brazilian music. Tropicália was a short-lived countercultural musical style which merged traditional Brazilian rhythms with rock and roll, banned in Brazil by the military government for its anti-authoritarian, revolutionary leanings. Gil and Veloso themselves were eventually forced into exile to London in $1969^{44}$.

43 Memories of Underdevelopment, directed by Tomás Gutierrez Alea (1968; Mr. Bongo Films, 2008). DVD.

44 Veloso, Caetano. Tropical Truth: A Story of Music \& Revolution in Brazil. New York, Alfred A. Knopf, 2002. 
1960 s youth culture was seen with suspicion by the radical wing of the Communist Party of Cuba, which after several mergers and mutations, was officially founded on October 3,1965 , as the only officially recognized political party in the island. Around this time, Cuban youth tastes were catching up with British and American pop and rock music. Radio and television, now under full control of the government, initially discouraged the diffusion of foreign music and by the end of the decade, the increasing interest in Anglo-American rock had become a matter of concern ${ }^{45}$. Including Queremos Guerra references these conditions, as well as the contradictions in the cultural policies of Cuba at the time. The song was featured in episode 469 alongside other songs that were presented by a voiceover: "For the first time, we listen in Cuba these protest songs, prohibited by the Brazilian military"46.

Third Movement (Battle Against Imperialism)

Aggressive guitars and syncopated basslines from the soundtrack of 79 Springs, Santiago Álvarez's documentary tribute to Ho Chi Min introduce this section. Joel del Rio explains the anti-imperialist and Latin American leanings that the director imprinted on the Noticiero. It segues into the the lushly orchestrated arrangements of Now, a song by Lena Horne which became the inspiration for the tour-de-force montage segment included in episode 272, and later released as a short film. Titled Now!, the film dealt with Civil Right Movement issued, and became the most known work by Álvarez. It is a synthesis of the most distinct elements of his oeuvre: skillful montage, playful and

45 Perna, The Sound of the Cuban Crisis, 29.

46 Noticiero ICAIC Latinoamericano. Episode 469. October 6, 1969. Digital file. 
evocative counterpoint between visual and musical rhythms, a balanced interplay between visual content and lyrics, but above all, its pamphletary commitment to antiimperialism and to international revolutionary struggle. A su propio ritmo is an homage to Santiago Álvarez work, and is deeply indebted to Now!'s formal and conceptual influence.

The images of Black Liberation struggles in the United States jump to the battlefields of Vietnam, as the ending gunshot sounds of Now! merge with the cacophony of bombs, airplanes, gunshots and keyboards of the soundtrack from the final scene of 79 Springs. Stylistically, this film created at the peak of Álvarez creative prowess, serves as background for Santiago Pérez's insights on the Noticiero as a group laboratory of creation and ideas. The Latin American struggle is also presented with images of armed conflict in Brazil, Chile, Colombia, Dominican Republic and Venezuela, backed by the relentless rhythms of Nothing Man by The Deviants (included in the soundtrack of episode 511), one of the tracks from Ptooff!, the band's 1967 debut album. The Deviants are a psychedelic rock band fronted by anarchist Mick Farren, a journalist by profession. The track features aggressive vocals by Farren, and a percussive groove and other sonic experiments crafted by Jack Henry Moore, a sound collector and central figure of the 1960s counterculture movement. Some of the track's aggressive lyrics (not included in the film): "The Nothing Man hates freaks, hates queers, hates niggers, hates kikes, hates, slobs, hates commie rats", turn it into a protopunk anthemic protest against the Establishment. 
Fourth Movement (Battle Against Dogmatism and Stagnation)

The intro section of Granma (1974), a collective work by GES, marks the entry of the Revolution into the 1970s. By this time, the government had imposed a dry-law and closed down most of the music clubs and cabarets in Havana ${ }^{47}$. The shut down was initially intended to help to concentrate all energies into the Zafra (sugar harvest) of 1970, a failed massive national effort to reach a sugar harvest of 10 million tons that would alleviate the by then evident economic shortcomings of the Revolution. But the moral austerity measures now in effect had an inhibitory effect in the production and diffusion of popular music in the island. Santiago Álvarez was the first director to start using the Group's musical output for the Noticiero and his own documentaries ${ }^{48}$. GES would eventually created incidental music and soundtracks for many of the Institute's documentary and fiction productions.

Granma, with its dark, ominous overtones also serves as an aural backdrop for the explorations of the Noticiero into the socioeconomic realities of Cuban society in the late 1970s and 1980s. Episode 1457 (released on September 22, 1989) shows the difficult conditions faced by the inhabitants of crumbling edifices in the marginal neighbourhoods in Havana. Fernando Pérez reminisces about the opposition faced by the Noticiero from ideologues of the Communist Party, who were bent in stopping them from releasing material critical of the regime. A scene taken from episode 821 (released

47 Perna, The Sound of the Cuban Crisis, 30.

48 Sarusky, Una Leyenda de la Música Cubana, 39. 
on July 7,1977$)$ reflects on a humorous way, the stock shortages and bureaucratic deficiencies in customer service that had become common all over the island.

This section closes with images of the last years of the Cold War in the different areas of conflict where it unraveled, especially in Central America and the Caribbean, accompanied by Toccata by Emerson, Lake and Palmer. This progressive rock piece is a reinterpretation of the fourth movement of Argentinian composer Alberto Ginastera's Concerto for Piano No.1, Opus 28 (1963). This piece was included on episode 1151 (released on November 12, 1983, 5 months after Ginastera's death), and its brutalist energy perfectly evoked the madness and terrifying nihilism of the nuclear arms race between the West and the Soviet Union in the final years of the Cold War. The adaptation of an Argentinian composer's neo-expressionist work of contemporary classical music by a British progressive rock band seemed to me as an appropriate choice that reflected the Zeitgeist of the last years of the Noticiero.

\section{Epilogue (Battle for Preservation)}

The frenetic pace of the film comes to a explosive halt. As Joel del Rio explains, one of the main reason for the death of the Noticiero was the inability to obtain the raw film from the East German manufacturers. During my initial visits at the ICAIC Film Labs, I noticed the abandoned machines previously used for duping and dubbing film and was informed that the machines were still operational. When I returned to shoot inside the labs, I asked the technicians to turn the machines on for me in order to film them. They asked if I needed some used film loaded onto the machines for filming but I 
declined the offer. Shooting the machines with no film running through them is a more accurate depiction of the current situation of the labs, where no film is processed anymore. A few of the technicians who worked processing film for ICAIC are still around, unable to practice their craft. I had informal interviews with them, and they shared colourful anecdotes about working with Santiago Álvarez and other directors of the Noticiero. I also filmed the conservation vaults where the restored reels of the Noticiero are now preserved, alongside the reels from the colour films produced by ICAIC (the black and white films are stored at a different location, at the former Cubanacan Studios west of Havana).

I recorded the sounds produced by the machines in motion, and used them as the soundbed for the final section of the film, alongside images of film being manipulated by operators of the Conservation Department. These technicians have the task of inspecting periodically all films in order to find potential degradation or damage to the reels. For the closing credits, I chose Changó by Celia Cruz, an Afrocuban chant recorded in 1957 and dedicated to Changó, Yoruba deity of war and thunder. Cruz, who went into exile after the triumph of the Revolution, became one of Latin America's most celebrated female music artists, and saw her music banned in Cuba for her strong opposition to the Revolution. Exiled in the early years of the Revolution, she never returned to Cuba. 


\section{DOCUMENTARY RELEVANCE}

“..Montage is not a simple succession of shots, nor even a sum of their contents, but produces something new, something original." (Esfir Shub)

The documentary tradition of using archival footage to tell a story, also know as compilation film, dates back to the very beginnings of filmmaking. Jay Leyda traces its origin to Edwin S. Parker's The Life of an American Fireman (1902), which used shots of fire department activities from Edison's earlier films to create a fictional story about a mother and daughter being rescued from a fire ${ }^{49}$. Film exhibitors saw a way to stretch their investments by re-editing and combining previously purchased films and newsreels into new stories, fueling the creation of compilation films.fuelling

Dziga Vertov's Kino-Nedelia newsreel series established his reputation as an innovative editor. He also created a few very successful compilation documentaries such as Anniversary of the Revolution (1918), and History Of The Civil War (1921), applying experimental montage techniques that created radical new meanings from the original material. But his aesthetically revolutionary style would eventually work against him, and in 1926 he was dismissed from his job at Sovkino (USSR State Committee for Cinematography, the Soviet equivalent of ICAIC). Recent shifts in the Soviet political climate had led critics and political elites to perceive avant-garde art as detached from the new sociopolitical order established by the revolution, and more 'accessible' socialist realism aesthetics began to take hold. While budgetary mismanagement was cited as

\footnotetext{
49 Leyda, Jay. Films Beget Films: A Study of the Compilation Film (New York: Hill and Wang, 1964), 14.
} 
the reason for his dismissal, the perceived 'difficulty' of his work by the government was seen as elitist and one-sided, and a return to 'clarity', and efficiency in linguistic and economic terms was mandated50.

Esfir Shub was appointed as Vertov's replacement at Sovkino, and she quickly received a commission to produce a film to commemorate the tenth anniversary of the Bolshevik Revolution. Her efforts resulted in The Fall of the Romanov Dynasty, ${ }^{11}$ a film with a total of 6000 feet composed of footage extracted from the film archives at the Museum of the Revolution in Leningrad, purchased material from the United States, as well as about 1000 feet of footage shot under Shub's supervision. ${ }^{52}$ Her approach to work with archival material was formally a radical departure from Vertov's style. She avoided to look "at the newsreel for its own sake, and to maintain the principle of its documentary quality"53. Repurposing and re-contextualizing newsreel material and private footage from the Romanov family originally meant to glorify the monarchy, Shub created a film that made a historical argument agains the old regime. The thematic, chronological way of organizing the material is punctuated with intertitles that at times advance the story, at times add commentary and perspective.

50 Malitsky, Post-Revolution Nonfiction Film, 159.

51 The Fall of the Romanov Dynasty, directed by Esfir Shub (1927; London, Eureka, 2002), DVD

52 lbid., 163.

53 Leyda, Films Beget Films, 25. 
Andrés Hernández argues that Cuban documentaries post-1959 fall into 6 categories: internal politics and mobilization, international relations, customs and folklore, historical, educational and newsreels 54 . Some documentaries may fall into one or more of these categories, and especially "educational", since by their very nature, documentaries aspire to illuminate or educate the audience about a specific topic. Hernández also raises the question if the ICAIC newsreels are actually documentaries. Referencing Julio García Espinosa, who explains that the newsreels "interrelate the news, making explicit the fact or concepts which provoke these interrelationships", and citing their elaborated editing and creative treatment of their content to extend their actuality, Hernández considers it fair to classify them as true documentaries. Joshua Malitsky, questions the status of the ICAIC newsreels as actual "news", and citing contemporaneity as a factor that distinguishes newsreels from documentaries, agrees that the Cuban newsreels were not "news" 55 . The fact is that, given the longevity of the Noticiero, it was almost inevitable that at one point or another, it would cover issues that belonged to any of those categories. Fiction filmmakers would go a few steps beyond those blurring lines, and often use material taken from documentary films and the Noticiero, most notably Sara Gómez in De cierta manera (One Way or Another) ${ }^{56}$, and Tomás Gutiérrez Alea who, in Memorias del subdesarrollo, included photos, archival audio recordings, extracts from pre and post-revolutionary newsreels, as well as hidden camera filming in the streets of Havana

54 Hernandez, The Heresy of Cuban Cinema, 375.

55 Ibid., 376.

56 De cierta manera, directed by Sara Gómez (1974, Havana, ICAIC), Digital file. 
In my film, I recall the documentary film tradition of the compilation film. Taking cues from Dziga Vertov and Esfir Shub, I appropriate archival footage from the 30 years of history of the Noticiero ICAIC in order to tell its own history. My intention is to evoke a sense of the history of the newsreel, using the individual voices of the people involved in its production or preservation.

\section{Participatory Poetry}

Bill Nichols identifies seven documentary modes: expository, observational, participatory, reflexive, poetic, performative and interactive. The participatory mode uses engagement such as interviews between filmmaker and subjects to develop a story or perspective ${ }^{57}$. An example of this mode is Emil De Antonio's In the Year of the Pig ${ }^{58,}$ uses extensive interviews and archival footage to tell the story of American involvement in the Vietnam War. The poetic mode creates aesthetically pleasing experiences that emphasize visual associations with strong tonal or rhythmic qualities in order to explain historical issues ${ }^{59}$. Santiago Alvarez uses a highly stylized and experimental approach in 79 Springs to pay tribute to the life of Ho Chi Minh.

Both 79 Springs and In the Year of the Spring provide insights into related a historical event, the Vietnam War, and a specific historical figure, Ho Chi Minh. They Both use archival film footage and photographs of Vietnam, its people and the war that 2017), 156.

57 Nichols, Bill. Introduction to Documentary (Bloomington: University of Indiana Press,

58 In the Year of the Pig. Directed by Emile de Antonio. New York City: Home Vision Entertainment, 2005. DVD.

59 Nichols, Introduction to Documentary, 22. 
afflicts them, but while De Antonio uses them in an more traditional, indexical form, Álvarez combination of text, disparate sources of music and extremes manipulation of the film stock take the film into experimental territory quite diametrically opposed to De Antonio's.

A su propio ritmo incorporates a mix of the participatory and poetic modes, utilizing the voices of the participants to tell the story of the Noticiero, while my use of montage and highly evocative soundtrack, take it into poetic territory. I also reverse Gutiérrez Alea use of documentary in fiction by bringing footage from Memories of Underdevelopment back into documentary, decontextualizing and recontextualizing it at the same time.

My film offers a poetic retelling of Cuba's history in the first 30 years of the Revolution. It's my intention to challenge the viewer's curiosity by offering them a glimpse of the story of the Revolution told from the Cuban side. It is also my hope to help expand a vision of Cuba that goes beyond the cliché images of vintage cars, decaying architectural jewels and sunny beaches. But most of all, it pays tribute to the Cuban people's struggle for their independence and self-determination. 


\section{CONCLUSION}

A su propio ritmo is a personal and poetic interpretation of the historical and audiovisual richness of the Noticiero ICAIC Latinoamericano. Emerging in the early 1960s as newsreels all over the world were being replaced by television as the main source of news, a Cuban group of filmmakers and technicians under the direction of Santiago Álvarez reinvented the newsreel form and lifted it to new heights. Produced under difficult conditions and with a sense of urgency, the Noticiero documented the revolutionary struggles of Cuba and other 'Third World' nations. Incorporated into UNESCO's Memory of the World Register and recently restored and digitized at the Institut National de l'Audiovisuel (INA) in France, the Noticiero gets a new lease on life.

As ICAIC looks for ways to shape the historical narrative of its cinematic production, and the role of the Noticiero in the nation building efforts of the young Republic, the management of the restored materials will be fundamental to the way the Institute's work will be perceived by future generations. In light of the changes implemented by Cuban president Raul Castro towards a more market-oriented economy, and the recent first steps into diplomatic relations with the United States, the Noticiero has gained even more importance as filmic testimony that reaffirms the achievements and shortcomings of the revolutionary movement. As a historic and even artistic document, the Noticiero ICAIC Latinoamericano is the most complete document of the first thirty years of the Cuban Revolution. Furthermore, it is one of the few documents in its format that registered the 70 s and the 80 s, a time when world 
production of the great majority of newsreels was ceasing due to the supremacy of television 60.

A su propio ritmo serves a reminder of the powerful imagery created by ICAIC, and the role Cuba played in "adding a new image to the iconography of the revolutionary movements in the world". 61

WORD COUNT: 8,985.

60 ICAIC. Memory of The World Registry Submission Form. (Habana: ICAIC, 2008), 3.

61 Hernández, Henry Eric. "Cine De Peregrinaje Político Hacia La Revolución Cubana. La Consolidación De Un Género Entre El Revolucionarismo y La Acosmía." Área Abierta no. 30 (2011). 


\section{Bibliography}

Agramonte, Arturo and Luciano Castillo. Cronología del Cine Cubano Volume III. Translated by Jorge Ayala. La Habana: Ediciones ICAIC,1965.

Amaya, Héctor. Screening Cuba: Film Criticism and Political Performance during the Cold War. Chicago: The University of Illinois Press, 2010.

Anderson, Alexandra. "Reflecting on Reality: The Place of Truth in Cuban and Canadian Documentary". Master's thesis, York University, 2003.

Buchsbaum, Jonathan. Cinema and the Sandinistas: Filmmaking in Revolutionary Nicaragua. Austin: University of Texas Press, 2003.

Burton, Julianne. "Democratizing Documentary: Modes of Address in the New Latin American Cinema, 1958-1972". In: The Social Documentary in Latin America. Pittsburgh, University of Pittsburgh Press, 2009.

Castillo, Luciano and Manuel Martínez Hadad. "Una entrevista inédita. Santiago Álvarez: (1919-1998). El documental como una actitud ante la vida". Translated by Jorge Ayala. Cine Cubano, no. 145 (1999).

Chanan, Michael. Cuban Cinema. Minneapolis: University of Minnesota Press, 2004.

Enzensberger, Masha. Dziga Vertov. Screen, Volume 13, Issue 4, 1 December 1972, Pages 90-107.

Garcia, Alicia, and Sara Vega. "El Periodismo Cinematográfico: Aventuras, Peripecias y Trascendencia". In Coordenadas del Cine Cubano 2. Edited by Mario Naito López. Translated by Jorge Ayala. Santiago de Cuba: Editorial Oriente, 2013.

González, Reynaldo, ed. Coordenadas del Cine Cubano 1. Santiago de Cuba: Editorial Oriente, 2013.

Hernandez, Andres R. "Filmmaking and Politics: The Cuban Experience". The American Behavioral Scientist, no. 17 (1974): 379.

Hernández, Henry Eric. "Cine De Peregrinaje Político Hacia La Revolución Cubana. La Consolidación De Un Género Entre El Revolucionarismo y La Acosmía." Área Abierta no. 30 (2011).

Historia de una batalla. Directed by Manuel Octavio Gómez. 1961. Havana, ICAIC. Digital file.

ICAIC. Memory of The World Registry Submission Form. La Habana: ICAIC, 2008. 
Kennedy, John F. "Remarks of Senator John F. Kennedy at Democratic Dinner, Cincinnati, Ohio, October 6, 1960". John F. Kennedy Presidential Library and Museum. https://www.jfklibrary.org/Research/Research-Aids/JFK-Speeches/ Cincinnati-OH_19601006-Democratic-Dinner.aspx.

Leyda, Jay. Films Beget Films: A Study of the Compilation Film. New York: Hill and Wang, 1964.

Malitsky, Joshua. Post-Revolution Non-Fiction Film: Building The Soviet and Cuban Nations. Bloomington: Indiana University Press, 2013.

McDonald, Theodor. Making A New People: Education in Revolutionary Cuba. Vancouver: New Start Book, 1985.

Myerson, Michael, ed. Memories of Underdevelopment: The Revolutionary Films of Cuba. New York: Grossman, 1973.

Memories of Underdevelopment, directed by Tomás Gutierrez Alea (1968; Mr. Bongo Films, 2008). DVD.

Muerte al Invasor. Directed by Santiago Álvarez and Tomás Gutiérrez Alea. 1961. Havana, ICAIC. Digital file.

Nichols, Bill. Introduction to Documentary. Bloomington: Indiana University Press, 2017.

Nosotros La Música. Directed by Rogelio París. 1964. Havana, ICAIC. Digital file.

Now!. Directed by Santiago Álvarez. 1965;. Havana, ICAIC. Digital file.

Pardo, José Manuel. "El cine-móvil [sic] ICAIC". Translated by Jorge Ayala. Cine Cubano, no.12, (1972): 93-101.

Perna, Vincenzo. Timba: The Sound of the Cuban Crisis. Burlington, Ashgate Publishing Limited, 2005.

Rodríguez, Paul Schroeder. The Heresy of Cuban Cinema. Chasqui: Nov 2008; 37, 2.

Sarusky, Jaime. Una Leyenda de la Música Cubana: Grupo de Experimentación Sonora del ICAIC. Translated by Jorge Ayala. La Habana: Editorial Letras Cubanas, 2006.

Schefer, Raquel. "The Return of The Newsreel (2011 - 2016) in Contemporary Cinematic Representations of the Political Event". Cinema Comparat/ive Cinema. Vol IV. No.9, 2016.

The Fall of the Romanov Dynasty. Directed by Esfir Shub. 1927. Moscow, Eureka, 2002. DVD.

Veloso, Caetano. Tropical Truth: A Story of Music \& Revolution in Brazil. New York, Alfred A. Knopf, 2002. 